УДК 351.82: 364

DOI https://doi.org/10.32836/2310-9653-2020-3.5

О. І. Білик, кандидат економічних наук, доцент, доцент кафедри адміністративного та фінансового менеджменту Національного університету «Львівська політехніка»

\title{
РОЛЬ ДЕРЖАВНОГО УПРАВЛІННЯ В ЗАБЕЗПЕЧЕННІ РОЗВИТКУ СОЦІАЛЬНОГО КАПІТАЛУ
}

У сучасних умовах економічної та соиіальної кризи, спричиненої пандемією COVID-19, перед владою стоїть гостро використання ефективних механізмів управління соиіальним капіталом. Вибір вірного напрямку в управлінні соиіальним капіталом забезпечить зменшення впливу соціальних ризиків та виникнення соціальної деструкції. У иіій статті авторкою проаналізовано роль державного управління в забезпеченні ефективності соиіального капіталу та сталого розвитку людини загалом. Новизна кониепиії державного управління у сфері розвитку соиіального капіталу полягає в тому, щзо вона робить акиент на те, щоб суспільство в иілому несло відповідальність за свій розвиток $і$ за допомогою обраних представників влади створювало умови для підвищення соціальних норм та стандартів, а також сталого людського розвитку.

Сталий людський розвиток в основному орієнтується на формування соиіального капіталу, який можна визначити як добровільні форми соиіального регулювання. Формування соиіального капіталу втілюється у відносинах між людьми; він закликає до їх активізаиї̈ з метою розширення своӥх можливостей, вибору та участі для досягнення спільних інтересів. Концепція також закликає пов'язувати демократію та розвиток, щоб підтримувати та сприяти взаємодії між державою та суспільством.

Державне управління - це нейтральна концепиія; яка позначає виконання політичним авторитетом завдання управління справами та ресурсами суспільства. Належне державне управління відбувається тоді, коли така практика перебуває в руках ефективного керівництва, відданого розвитку ресурсів суспільства, просуванню громадян та їх добробуту за їх згодою, участю та підтримкою. У статті визначено, щзо для державного ефективного управлінням необхідно враховувати три вектори правління суспільством: політичний вектор, який включає політичну владу та управління (публічна сфера); технічний вимір, представлений ефективним державним управлінням; і соціальний вимір, пов'язаний із структурою суспільства, його життєздатністю та ставленням до держави.

Ключові слова: державне управління, соиіальний капітал, соціальний ризик, людський розвиток, корупџія.

\section{O. I. Bilyk. The role of public governance in ensuring the development of social capital}

In the current economic and social crisis caused by the COVID-19 pandemic, the authorities are facing the acute use of effective mechanisms for managing social capital. Choosing the right direction in the management of social capital will reduce the impact of social risks and the emergence of social destruction. In this article, the author analyzes the role of public administration in ensuring the effectiveness of social capital and sustainable human development in general. The novelty of the concept of public administration in the field of social capital development is that it emphasizes that society as a whole is responsible for its development and with the help of elected officials to create conditions for improving social norms and standards and sustainable human development.

Sustainable human development is mainly focused on the formation of social capital, which can be defined as voluntary forms of social regulation. The formation of social capital is embodied in relations between people; it calls for them to be stepped up in order to empower, choose and participate to achieve common interests. The concept also calls for linking democracy and development to support and promote interaction between the state and society.

Public administration is a neutral concept; which signifies the fulfillment by a political authority of the task of managing the affairs and resources of society. Good governance occurs when such practices are in the hands of effective leadership, committed to the development of society's resources, the promotion of citizens and their well-being with their consent, participation and support. The article defines that for effective public administration it is necessary to take into account three vectors of governing society: the political vector, which includes political power and management (public sphere); technical dimension represented by effective public administration; and the social dimension related to the structure of society, its viability and attitude to the state.

Key words: public administration, social capital, social risk, human development, corruption.

Постановка проблеми. Сталий людський розвиток зумовлений політичною, економічною, соціальною, екологічною та культурною стійкістю; а хороше управління - це основа політичної стійкості, яка, своєю чергою, забезпечує зв'язок між елементами, що гарантують розвиток соціального капіталу, враховуючи взаємозв'язок з багатьма факторами. Соціальний капітал, присутній у країні, все частіше розглядається як важливе джерело копродуктивного потенціалу для надання кращих державних послуг. Однак сьогодні дослідження в галузі державного управління приділяють мізерну увагу зв'язкам між структурними та ставленими компонентами соціального капіталу, такими як суспільне життя громади, політична заангажованість та рівень

등. І. Білик, 2020 
міжособистісного довіри, ефективність державних послуг та корупційні ризики. У цій статті взаємозв'язок між соціальним капіталом та виконанням публічних послуг досліджується шляхом перегляду наявних емпіричних доказів з цієї теми. Наявні факти свідчать про те, що сила та спрямованість взаємозв'язку ефективності соціального капіталу можуть змінюватися залежно від різних вимірів соціального капіталу. Таким чином, подальші дослідження в цій галузі матимуть теоретичну та практичну користь.

Аналіз останніх досліджень і публікацій. Дослідження суті та значення розвитку соціального капіталу дослідували у своїх працях такі відомі науковці, як П. Бурдьє [1], Дж. Коулман [2], Д. Норт [3], Р. Патнем [4], Ф. Фукуяма [5], В. І. Чаленко [6]. Серед вітчизняних науковців проблематику теорії та методології людського капіталу висвітлили у своїх працях Д. Богиня [7], В. Воронкова [8], О. Грішнова [9], Е. Лібанова [10], А. Мерзляк [11], Л. Михайлова [12]та ін. Проте у цій статті підсумовується стан досліджень 3 питання розвитку соціального капіталу шляхом перегляду емпіричної літератури про взаємозв'язок між соціальним капіталом та виконанням державних послуг.

Метою статті $є$ визначення умов розвитку соціального капіталу в Україні з визначенням ролі державного управління.

Виклад основного матеріалу. Розвиток соціального капіталу є важливим у сучасних умовах. Для аналізування основних напрямків розвитку необхідно визначити поняття «соціальний капітал». Згідно із класичними дослідженнями (П’єр Бурдьє, Роберт Путнам, Джол Коулман, Френсіс Фукуяма), соціальний капітал визначається як потенціал співпраці, закладений у соціальні зв'язки та норми, які можуть принести користь окремим особам, групам та суспільству. Проте в демократичному середовищі соціальний капітал набуває все вагомішого значення: поняття соціального капіталу все більше розгортається в низці важливих сфер державної політики та управління. У межах будь-якого регіону чи адміністративної одиниці та ставлення до соціального капіталу включатиме такі елементи, як організаційне життя громади, політична участь та рівень міжособистісного довіри, враховуючи запас матеріальних, культурних та людських ресурсів, які потенційно можуть бути використані для громадських цілей, а також і в державному управлінні. Важливим є те, що розвинений соціальний капітал є одним із інструментів мінімізації соціальних ризиків, створюючи необхідні механізми щодо розвитку інститутів освіти, здоров'я, охорони довкілля, а також і різнопланові інтерактивні політичні інститути. Саме дотримуючись позиції щодо наявності інтерактивних політичних інститутів, висунутої такими дослідниками, як Дарон Аджемоглу та Джеймс Робінсон [13], детермінуємо поняття розвитку соціального капіталу як покращення якісних і кількісних соціальних показників держави, що виражається в рівні задоволення життя окремого індивіда або групи індивідів, враховуючи моральні норми або звичаї, що пов'язують індивіда із суспільством таким чином, що дозволяє йому взаємодіяти з іншими для загального блага, що забезпечується якісними державними інституціями.

Проте соціальний капітал концептується в емпіричній літературі як латентна конструкція, яку неможливо безпосередньо спостерігати, тобто соціальний капітал складається з окремих, хоча взаємозалежних вимірів, які піддаються спостереженню. У США Робертом Путнамом було виділено такі виміри соціального капіталу: організаційне життя громади, залучення до державних справ, громадський волонтерство, неформальна товариськість та соціальна довіра. Кожен із цих вимірів включає в себе характерні аспекти зв'язку (виключного) та інклюзивного аспектів, які можуть підкріплювати ексклюзивні ідентичності або охоплювати безліч різноманітних способів, які можуть або не можуть сприяти суспільному благам [14].

Дотримуючись окресленого визначення, виділимо такі напрямки дослідження розвитку соціального капіталу в Україні:

1) соціальна комунікація;

2) соціальна взаємодія та участь;

3) участь у державному управлінні;

4) культура та творчість;

5) соціальна довіра.

Зв'язки, засновані на довірі та знайомості - складових частинах соціального капіталу, - приносять користь людям так, як вони часто не впізнають. Але оскільки подібні концепції практично відсутні на публічній площі, дебати щодо політики нерівності в основному обрамлені деякими серйозними (і багатьма несерйозними) ідеями щодо субсидій на заробітну плату, гарантованих робочих місць, учнівства, кар'єри та технічної освіти. Слід врахувати і те, що соціальний капітал не дорівнює узагальненому поняттю довірі: тільки сплітаючись, ці два типи утворюють базову довіру, без якої можуть виникнути інші механізми, що забезпечують ефективні та стабільні соціально-економічні процеси.

Оцінюючи розвиток соціального капіталу, слід проаналізувати його основні детермінанти, тобто рівень довіри та стан третього сектору в суспільстві, що співвідноситься з рівнем громадянського суспільства (табл. 1). 
Таблиця 1

Система показників розвитку соціального капіталу

\begin{tabular}{|c|c|}
\hline $\begin{array}{c}\text { Напрямки розвитку соціального } \\
\text { капіталу з врахуванням пріоритетності }\end{array}$ & Довіра індивідів до інших \\
\hline \multirow{4}{*}{ Напрям 1} & кількість активних асоціацій, фондів та інших соціальних організацій \\
\cline { 2 - 2 } & явка виборців на місцевих виборах \\
\cline { 2 - 2 } & відсоток домогосподарств з доступом до Інтернету \\
\cline { 2 - 2 } & $\begin{array}{c}\text { частка витрат бюджету органів місцевого самоврядування } \\
\text { на культуру та охорону національної спадщини }\end{array}$ \\
\hline \multirow{4}{*}{ Напрям 2} & відсоток платників податків, які жертвують 1\% організаціям, \\
& що надають суспільні послуги \\
\cline { 2 - 2 } & відсоток соціальних організацій, що співпрацюють з державним управлінням \\
\cline { 2 - 2 } & відсоток домогосподарств, оснащених телевізором \\
\cline { 2 - 2 } & кількість одержувачів пропозиції закладів культури \\
\hline \multirow{2}{*}{ Напрям 3 } & відсоток громадян, зайнятих добровільною роботою \\
\cline { 2 - 2 } & відсоток офісів, що співпрацюють з неурядовими організаціями \\
\cline { 2 - 2 } & читання газет і журналів на душу населення \\
\cline { 2 - 2 } & відсоток цифрових колекцій у бібліотеках \\
\hline
\end{tabular}

Із метою визначення напрямків розвитку соціального капіталу слід здійснити СВОТ-аналіз стану соціального капіталу в Україні (рис. 1).

\begin{tabular}{|c|c|}
\hline Сильні сторони & Слабкі сторони \\
\hline $\begin{array}{l}\text { Зростання рівня освіти } \\
\text { Доступність до інформації } \\
\text { Сильний третій сектор }\end{array}$ & $\begin{array}{l}\text { Низький рівень соціальної довіри } \\
\text { Відсутність цілісної системи розвитку компетентностей } \\
\text { у соціальній сфері } \\
\text { Наявність корупційних ризиків } \\
\text { Фінансово-економічні проблеми }\end{array}$ \\
\hline Можливості & Загрози \\
\hline $\begin{array}{l}\text { Розвиток інтелектуального капіталу } \\
\text { Розвиток процесу децентралізації } \\
\text { Удосконалення та подальше впровадження реформ } \\
\text { (освіти, медицини, пенсійної реформи, } \\
\text { управління державними фінансами) } \\
\text { Імплементація в європейський простір } \\
\text { Впровадженні в освітній процес та в інформаційну } \\
\text { політику держави значення для держави розвитку } \\
\text { соціального капіталу }\end{array}$ & $\begin{array}{l}\text { Відсутність усвідомлення важливості соціального капіталу, } \\
\text { Повільна проходження реформ, } \\
\text { Нерозуміння значення реформ, } \\
\text { Політична криза (військові дії на Сході України), } \\
\text { Фінансово-економічна криза }\end{array}$ \\
\hline
\end{tabular}

Рис. 1. СВОТ-аналіз стану соціального капіталу в Україні

Отже, з метою забезпечення розвитку соціального капіталу державне управління повинно бути зосереджене на розвиток людського і інтелектуального капіталу шляхом створення умов для отримання якісних освітніх, медичних послуг, сприяння розвитку культури та підтримання історичної, духовної спадщини, забезпечити охорону довкілля шляхом інвестування у сміттєпереробну галузь, розвитку альтернативних джерел енергії та підтримки сільського господарства тощо. Ці елементи є визначальними не лише в системі розвитку соціального капіталу, але й для формування ефективного державного управління, що дасть змогу мінімізувати цілу низку ризиків, серед яких визначальними є корупційні і соціальні ризики. Питання соціального капіталу та виконання державних послуг набуває все більшого інтересу та значення. Спроби поєднати продуктивні зусилля постачальників послуг та користувачів послуг лежать в основі численних реформ, спрямованих на покращення управління та надання державних послуг. Також слід відзначити, що для покращення розвитку соціального капіталу важливим є усунення або мінімізація корупційних ризиків, зокрема на всіх рівнях влади, що дасть можливість забезпечити довіру населення, врегулює ринок праці, забезпечить підвищення ефективності витрат бюджетної сфери. Наявні емпіричні дослідження підтверджують деякі аргументи щодо переваг (і в меншій мірі витрат) соціального капіталу для надання державних послуг та потенційних переваг державних послуг для соціального капіталу. Виявляється, що кожен вимір соціального капіталу (крім неформальної комунікабельності) має позитивний зв’язок на ринку праці, а також підприємств, установ, організацій, які здійснюють свою діяльність на засадах неприбутковості, як урядового, так і неурядового типу. Схоже, це стосується більшості аспектів діяльності, а також 
у кількох організаційних умовах, що дозволяє припустити, що райони з високим рівнем соціального капіталу можуть бути більш стійкими до економічного спаду та скорочення бюджету.

Висновки 3 дослідження і перспективи подальших розвідок у цьому напрямі. Значна частина даних, отриманих із досліджень у Сполучених Штатах [14-16], вказує на потенційно велику роль, яку має відігравати державна політика у формуванні позитивних асоціацій між соціальним капіталом та покращенням послуг. Тому важливим є необхідність розуміння проблем, пов'язаних із розробкою та впровадженням ефективних ініціатив спільного виробництва, які можуть успішно об'єднати громадян та постачальників послуг. Те, як громадські організації вирішують ці виклики, матиме глибокі наслідки для теорії та практики публічної політики та управління в наступні роки.

\section{Список використаних джерел:}

1. Бурдье П. Формы капитала. Экономическая соичилогия. 2002. № 5. С. 60-75.

2. Коулман Дж. Капитал социальный и человеческий. Общеественные науки и современность. 2001. № 3. С. 122-139.

3. Норт Д. Институты, институциональные изменения и функционирование экономики. Москва : Фонд экономической книги «Начала», 1997. 188 с.

4. Патнем Р. Процветающая комьюнити, социальный капитал и общественная жизнь. Мировая экономика и международные отношения. 1995. № 4. С. 77-86.

5. Фукуяма Ф. Доверие: социальные добродетели и путь к процветанию. Москва, 2008. 730 с.

6. Чаленко В.И. Некоторые подходы к оценке величины социального капитала экономической системы Сфера услуг: инновации и качество. 2011. № 1 .

7. Богиня Д.П., Грішнова О.А. Основи економіки праці : навч. посіб. Київ : Знання-Прес, 2000. 313 с.

8. Воронкова В. Менеджмент у державних організаціях : навч. посіб. Київ : Вид-во «Професіонал», 2004. $256 \mathrm{c}$

9. Грішнова О.А. Людський капітал: формування в системі освіти і професійної підготовки. Київ : Т-во «Знання», КОО, 2001. С. 16-17.

10. Мерзляк А.В. Тенденції і закономірність формування та використання внутрішніх джерел інвестиційних ресурсів регіону. Зб. наук. пр. УАДУ. 2002. № 3. С. 108-118.

11. Лібанова Е. Соціально-економічна політика держави та ії вплив на зміну соціальної структури суспільства. Украӥна: аспекти праціi. 1999. № 8. С. 21.

12. Михайлова Л.І. Людський капітал сільського господарства України в транзитивній економіці. Економіка АПК. 2001. № 12. С. 89-93.

13. Аджемоглу Д. Чому нації занепадають? Походження влади, багатства і бідності / пер. 3 англ. Олександр Дем’янчук. Київ : Наш Формат, 2016. 440 с.

14. Putnam R. Bowling Alone: The Collapse and Revival of American Community . New York : Simon \& Schuster, 2000. $330 \mathrm{c}$.

15. Boix C. Social capital: explaining its origins and effects on government performance. British Journal of Political Science. 1998. № 28. C. 686-693.

16. Borge L. Public sector efficiency: the roles of political and budgetary institutions, fiscal capacity and democratic participation. Public Choice. 2008. № 136. C. 475-495.

17. Bourgon J. New directions in public administration: serving beyond the predictable. Public Policy and Administration. 2009. № 3. C. 309-330.

\section{References:}

1. Bourdieu P. (1986) The forms of capital. Cultural theory: An anthology, 5, 81-93.

2. Coleman J. S. (2001) Social capital in the creation of human capital. American journal of sociology, 3, 95.

3. Douglass N (1990) Institutions, institutional change and economic performance. Cambridge university press, P. 18.

4. Putnam R. D. (1995) Bowling alone: America's declining social capital Journal of democracy. 6, 1, 65-78.

5. Yoshihiro Francis Fukuyama (1995), Trust: The Social Virtues and the Creation of Prosperity. Free Press, P. 133.

6. Chalenko V. Y. (2011) Some approaches to assessing the value of social capital of the economic system Sfera usluh: ynnovatsyy y kachestvo. 1 .

7. Bohynia D.P.\& Hrishnova O.A. (2000) Fundamentals of labor economics: textbook. way. K, Znannia-Pres, P. 313.

8. Voronkova V. (2004) Management in government organizations: A textbook. K. Vyd-vo «Profesional», P. 256.

9. Hrishnova O.A. (2001) Human capital: formation in the system of education and training. K. T-vo "Znannia", KOO, 16-17.

10. Merzliak A.V. (2002) Trends and patterns of formation and use of internal sources of investment resources in the region $Z$ b. nauk. pr. UADU, 3, 108-118. 
11. Libanova Ye. (1999) Socio-economic policy of the state and its impact on changing the social structure of society. Ukraina: aspekty pratsi. 8, 21.

12. Mykhailova L.I. (2001) Human capital of agriculture in Ukraine in a transitional economy . Ekonomika APK., 12., 89-93.

13. Daron Acemoglu, James A. Robinson (2016) Why Nations Fail: The Origins of Power, Prosperity and Poverty. New York: Crown Publishing Group, 440 p.

14. Putnam R (2000) Bowling Alone: The Collapse and Revival of American Community. New York: Simon \& Schuster.

15. Boix C and Posner DN (1998) Social capital: explaining its origins and effects on government performance. British Journal of Political Science 28(4), 686-693.

16. Borge L-E, Falch T and Tovno P (2008) Public sector efficiency: the roles of political and budgetary institutions, fiscal capacity and democratic participation. Public Choice 136, 475-495.

17. Bourgon J (2009) New directions in public administration: serving beyond the predictable. Public Policy and Administration 24(3), 309-330. 